\title{
International Diversity in Measuring the Fair Value of Life Insurance Contracts*
}

\author{
Paul J.M. Klumpes ${ }^{\mathrm{a}}$, Christopher D. O’Brien ${ }^{\mathrm{b}}$ and Andres Reibel ${ }^{\mathrm{a}}$ \\ ${ }^{a}$ Imperial College Business School, Imperial College, Exhibition Road, South Kensington Campus, \\ London SW7 2AZ, U.K. \\ ${ }^{\mathrm{b}}$ Centre for Risk and Insurance, Nottingham University Business School, Jubilee Campus, \\ Nottingham NG81BB, U.K.
}

This paper discusses international diversity in accounting for insurance contracts as reported under various Generally Accepted Accounting Principles (GAAPs) in Australia, Canada, the U.K. and the U.S.A. Relative to statutory-based accounting principles, existing GAAPs allow insurance firms to match income to expenses over the term of an insurance contract in order to provide a more "realistic" basis for reporting to shareholders. However, those GAAPs do not employ a coherent and consistent view of how to measure the fair value of a life insurance firm's business. The International Accounting Standards Board (IASB) has tentatively concluded that fair value should be used in accounting for insurance contracts. This paper discusses how existing GAAPs differ from fair values and simulates their impact on the profits emerging on a simple endowment policy. We also consider Solvency II as providing a broader conceptual fair value-based framework within which additional risk-related disclosures can address currently unresolved conceptual and practical problems in implementing fair value for insurance contracts and related financial instruments. These recommendations are likely to bear upon current deliberations by the IASB on financial instruments and life insurance accounting. The Geneva Papers (2009) 34, 197-227. doi:10.1057/gpp.2009.7

Keywords: GAAP; life insurance; reporting

\section{Introduction}

The determination of profits attributable to life insurance business is complex, due to (i) uncertainty as to future cash flows emanating from an insurance contract at the point of sale; and (ii) different approaches as to how those cash flows should be incorporated into the entity's financial statements. ${ }^{1}$ Thus a major problem in accounting for life insurance contracts is how to determine an appropriate way of reflecting the riskiness of a life insurance firm's activities in its published financial statements. Since the economics of life insurance transactions differ substantively in this respect from other enterprises, another major issue facing accounting standard

\footnotetext{
* We appreciate comments provided on an earlier draft by Marianne Pitts, Rob Bryer and participants at an accounting workshop at the University of Warwick.

${ }^{1}$ Adams and Scott (1994).
} 
setters is to ensure that these treatments are broadly consistent with both their conceptual frameworks and similar non-insurance transactions that are entered into by these same enterprises (e.g. pensions, financial instruments, banking).

A particular issue is how profit emerges over the lifetime of life insurance contracts, which may last many years. Current accounting practices for insurance contracts that are incorporated into national Generally Accepted Accounting Principles (hereinafter "GAAP") in what we shall call G4 countries (the U.S., U.K., Australia and Canada) are largely based on income measured in terms of accrual-based deferral and matching principles, where the driver is the desire to match income and expenditure in the revenue account. However, countries differ as to how they apply this.

In a number of jurisdictions (including European Union and Australia) some insurers were required, by 2005, to have financial statements that comply with International Financial Reporting Standards (hereinafter "IFRS"). There was therefore pressure on the International Accounting Standards Board (hereinafter "IASB") to issue a standard applicable to insurance contracts at an early date. However, resolving the many issues was taking a long time, since there was no consensus over the measurement of assets and liabilities. ${ }^{2}$ Consequently, the project was divided into two phases. ${ }^{3}$ Phase I concentrated on removing those insurance accounting practices regarded as most clearly inconsistent with IASB principles, and the outcome was a standard, IFRS $4,{ }^{4}$ effective for annual periods beginning on or after 1 January 2005. This introduced some new requirements on disclosures by insurers, namely the disclosure of assumptions, sensitivity analysis and information about the management of these risks.

Phase II aims to conclude on the more significant conceptual issue of the recognition and measurement for insurance contracts; however, the IASB indicated its tentative conclusion that the assets and liabilities of insurers should be measured consistently at fair value. ${ }^{5}$ Insurance firms therefore provide an important test case for the potential breadth of the applicability of fair value accounting. Fair value is "the amount for which an asset could be exchanged, or a liability settled, between knowledgeable, willing parties in an arm's length transaction". ${ }^{6}$ It has been a central concept in all the last three Standards issued by the old IASC. ${ }^{7}$ The IASB thus treats life insurance firms' assets and liabilities as primarily financial instruments, and goes on to regard them as amenable to fair valuation.

However, the IASB's views on fair value for insurance do not accord either with existing national GAAP practices, or with the lack of observable market prices for insurance liabilities. This therefore presents a considerable challenge, especially as fair value does not feature among the diverse GAAPs of G4 countries. This paper

\footnotetext{
2 Economist (23 October 2004).

${ }^{3}$ The project was initiated by the IASB's predecessor, the International Accounting Standards Committee. The Steering Committee has subsequently been issuing sections of a Draft Statement of Principles (IASB, 2002).

${ }^{4}$ IASB (2004).

5 Idem.

${ }^{6}$ IFRS 4, para. 23

${ }^{7}$ IASs 39,40 and 41.
} 
proposes a general conceptual framework which recognises three elements of valuation and their various purposes. First, it is recognised that the fair value of insurance liabilities can be difficult to determine as such liabilities are not commonly traded, and entity-specific values may be acceptable to determine the franchise value of the business. ${ }^{8}$ Second, we provide a critique of the proposed fair value measurement basis for life insurance contracts. In the absence of market evidence to the contrary, the estimated fair value of an insurance contract should be not less than the insurer would charge a new policyholder for a new contract with identical terms over the remaining duration of the contract. Third, the framework explicitly identifies the regulatory risk of insolvency associated with various complex options underlying the insurance business.

The rest of the paper is organised as follows. First, the principles of life insurance valuation are outlined. Then major differences between insurance GAAP in the G4, and their differences from the "fair value" approach favoured by IASB are outlined. Major conceptual difficulties in using fair value for insurance profit reporting are then discussed. We then propose a broader Solvency II-based conceptual financial reporting framework wherein the major implicit and explicit options and their related risks associated with fair valuation is disclosed. Additional risk disclosures relating to credit risk, interest rate risk, market risk and liquidity risk exposures to contractual liabilities are then proposed.

\section{Life insurance valuation principles}

In order to put these developments in context, it is important to review the principles of life insurance valuation. This is an area where actuaries ${ }^{9}$ have made important contributions in developing insurance accounting.

Life insurance firms manage assets in order to meet present and future policy obligations which possess three unique features. First, it is generally the case that most assets of life insurers are cash or financial instruments that are readily realisable, and the fair value can be determined without undue difficulty (assuming that definitional issues such as use of entry or exit price have been decided). Second, many of the assets held by life insurers are equities, where amortised value is impracticable. Third, some authors highlight the importance of prudence ${ }^{10}$ : confidence in the sector may be enhanced if insurers are seen to be solvent with a deliberately prudent value placed on their assets, for example by using the lower of purchase price and market value.

It is important to have consistency in the method of valuing assets and liabilities. A key reason for this is that many life insurance policies have the value of the claim

\footnotetext{
${ }^{8}$ In the U.K. there are a number of firms who buy and sell with profit endowment insurance contracts. The trading values exceed the surrender values offered by life insurers (McGurk, 1998). The market does not cover all policies, for example, short-term policies and it may not be regarded as especially liquid. Nevertheless, it is a useful point of comparison for the tests being carried out on what fair value calculations might be.

${ }^{9}$ For example, Skerman (1966).

${ }^{10}$ Welzel (1996).
} 
determined with reference to asset values. For example, the investment risk on unitlinked policies is borne by policyholders: the payout is reduced if the value of the assets backing the policy falls.

Valuing liabilities raises some other difficult issues. There is no liquid, active secondary market in life insurance policies, at least in most cases, so it is not surprising that life insurers have, to date, shied away from trying to make an estimate of what a market value would be. Instead, their valuations have been based on the expected cash flows on the policies still in force: they use the discounted value of claims and expenses payable in excess of future premiums receivable. ${ }^{11}$ However, such a calculation is not straightforward. The insurer's obligation is to pay claims at future dates that are, as yet unknown, depending on contingencies such as death, sickness and policyholders' surrenders. The amount of claims may also be uncertain, as it can depend on future financial conditions and the way in which the directors exercise discretion on with profit policies to declare bonuses for policyholders. Future expenses and premium receipts are also uncertain, while the way in which discounting should be applied is also open to question.

The IASB's Issues Paper ${ }^{12}$ on life insurance accounting raised a number of questions about the liability valuation. This process requires assumptions about future rates of mortality, expenses, taxes, investment returns, etc. A number of questions were identified, such as whether the future cash flows used were based on assumptions about mortality, etc. that were decided at the outset when the policy was sold; or are the assumptions updated as estimates of future conditions change? If there is a change in, say, assumed mortality rates, is the effect capitalised into the year's result or is the effect spread over time?

\section{Insurance accounting in the G4 - an overview}

In view of these difficulties, existing national GAAPs have made various efforts to estimate, when each policy is sold, the expected profit over its lifetime, and spread such profit over the duration of the policy in proportion to a "profit carrier" such as premiums, in which case it is payment of a premium that generates profit. In some approaches multiple profit carriers may be permitted. This is a particular area of diversity in existing practices.

Life insurers produce financial statements not only for their accounts but also for the industry regulators. Historically, financial statements for U.K. life insurance companies were required for prudential regulation purposes, that is, to use overly conservative estimates of assets and liabilities, primarily in order to protect their policyholders. ${ }^{13}$ Life insurance actuaries produce valuations of assets and liabilities in accord with industry-specific "solvency accounting principles" (hereinafter "SAP"). Such valuations are also used to determine the surplus which can be transferred to the

\footnotetext{
${ }^{11}$ Booth et al. (1998).

12 IASB's Issues Paper (1999).

${ }^{13}$ Horton and Macve $(1995,1999)$.
} 
Table 1 Comparison of GAAP reporting methods

\begin{tabular}{|c|c|c|c|c|c|}
\hline Country & Australia & Canada & U.K. & U.S.A. & U.S.A. \\
\hline \multirow[t]{2}{*}{ Method } & AASB 1038 & Canadian & Draft SORP & U.S. GAAP & U.S. GAAP \\
\hline & & GAAP & U.K. GAAP & FAS 60 & FAS 97 \\
\hline Date adopted & 1998 & 1992 & Exposure draft & 1982 & 1988 \\
\hline Asset values & Market value & $\begin{array}{l}\text { Smoothed } \\
\text { market value }\end{array}$ & Market value & Book value & Market value $^{\mathrm{a}}$ \\
\hline Lock-in of assumptions? & No & No & No & Yes & No \\
\hline $\begin{array}{l}\text { Capitalise assumption } \\
\text { changes? }\end{array}$ & No & Yes & Yes & NA & Yes \\
\hline $\begin{array}{l}\text { Single or multiple } \\
\text { profit carriers? }\end{array}$ & Either & Multiple & NA & Single & Single \\
\hline Discount rate & $\begin{array}{l}\text { Net earned } \\
\text { rate }\end{array}$ & $\begin{array}{l}\text { Net earned } \\
\text { rate }\end{array}$ & $\begin{array}{l}\text { Risk discount } \\
\text { rate }\end{array}$ & $\begin{array}{l}\text { Pre-tax net } \\
\text { earned rate }\end{array}$ & $\begin{array}{l}\text { Pre-tax } \\
\text { credited rate }\end{array}$ \\
\hline $\begin{array}{l}\text { Allowance for cost of } \\
\text { solvency reserves }\end{array}$ & No & No & Yes & No & No \\
\hline Profit recognised at sale? & No & Partially & Yes & $\mathrm{Yes} / \mathrm{No}^{\mathrm{b}}$ & $\mathrm{Yes} / \mathrm{No}^{\mathrm{b}}$ \\
\hline Relation to SAP? & $\begin{array}{l}\text { Same } \\
\text { (after 1996) }\end{array}$ & $\begin{array}{l}\text { Same } \\
\text { (after 1992) }\end{array}$ & Differs & Differs & Differs \\
\hline
\end{tabular}

${ }^{\mathrm{a} A s s e t s ~ m a r k e d ~ t o ~ m a r k e t ~ u n d e r ~ S F A S ~} 115$.

${ }^{\mathrm{b}}$ Varies by product.

shareholders' funds and what can be allocated to policyholders in the form of participatory bonuses or dividends. ${ }^{14}$

Because SAP reflects regulators' requirements, it may well lead to an understatement of assets and overstatement of liabilities compared with what would be expected from compliance with GAAP. Furthermore, the writing of new policies, with high initial expenses, typically depresses profits on a SAP basis. So while SAP may be appropriate for providing protection to policyholders, the accounts prepared on this basis would, in a growing business, understate reported profits, hence making them unsuitable for the purpose of reporting to shareholders.

Recent trends towards de-regulation and consolidation of the global financial services industry, together with general dissatisfaction with SAP by financial analysts and other users led to the development of GAAPs in each of the G4 countries. GAAP is intended to provide shareholders and other users with more "realistic" measures of a life insurer's financial position. However, this development has not been on a consistent basis. Table 1 summarises major differences between the G4 countries.

In the U.S., the Financial Accounting Standards Board (FASB) has issued a number of accounting standards that apply to various types of insurance contracts. The first of these, FAS 60, was issued in 1982 and applies to many traditional non-profit life insurance policies. However, because of concern that the high costs of acquiring business (in particular, commission) may depress revenue unduly, an additional asset

${ }^{14}$ SAP typically uses assets at market value or below and liabilities which are inflated by conservative assumptions regarding future investment returns and mortality, which are typically set aside in the form of provisions or reserves. Reserves are retained to meet future policy liabilities, expenses and contingencies and to fund a smooth distribution of surplus (Horton and Macve, 1995, p. 270). 
202

is created: deferred acquisition costs (DAC), being such costs that are said to be matched by margins in premiums payable in subsequent years. The DAC asset is then amortised in proportion to premiums paid under the contract. This reflects the FASB view that although the point of sale of the contract is the primary event in the life insurance accounting cycle, it is not the whole transaction: premiums are a "profit carrier".

Under FAS 60, liabilities are valued using all relevant applicable assumptions where such assumptions are chosen as "actuarial best estimate" plus a provision for adverse deviation, that is, there is an element of conservatism. Those assumptions, once chosen, are "locked in", that is, they cannot be changed unless severe adverse experience developed in the future.

FAS 60 earnings therefore emerge as a level per cent of premium revenue, plus an "adjusted expectations" portion relating to: (i) the release from risk which occurs as actual experience emerges more favourably than that assumed in valuing the liabilities; and (ii) any deviation of actual experience than expected. The outcome is that earnings emerge over the entire life of the block of business.

However, the implementation of FAS 60 during the 1980s raised a number of issues. First, some insurance companies applied FAS 60 literally when preparing GAAP financial statements for single premium deferred annuities. Often there was little provision for adverse deviation, so that the majority of profit was released in proportion to premium; that is, in the year of issue. This approach "front-ended" earnings.

The concern raised by this practice was heightened by the fact that one of the companies using that practice became insolvent. Second, universal life, with its flexible premiums that reflect policy holders' changing economic circumstances over time, became a major life insurance product. Since premiums were flexible, their use as the basis of revenue creates volatility in the reported earnings of insurance companies selling significant amounts of these products. ${ }^{15,}{ }^{16}$ While some volatility was to be expected, this highlighted the issue of whether it was valid to deem that profits related to premiums receivable rather than also to other factors. New accounting principles were developed to address insurance contracts that did not easily fit traditional contracts and their associated accounting techniques. ${ }^{17}$ However each model for longduration contracts produces different patterns of reported income: for example, if provisions for adverse deviation are not permitted in calculating liabilities. ${ }^{18}$

These limitations of U.S. GAAP were partially addressed by Australian GAAP, first developed in the early 1990s and subsequently issued by the Australian Accounting

\footnotetext{
${ }^{15}$ Becker (1998).

${ }^{16}$ However while SFAS 115 required U.S. insurance firms to adopt partial fair value for their investment securities, their insurance liabilities were still subject to conservative book value amortisation rules in accord with SFAS 60 or SFAS 97, thus potentially understating the net worth, and created a higher probability of negative amortisation of DAC. In December 1993 the SEC realised the potential impact in financial reporting for financial institutions due to SFAS 115. As a result, the SEC issued instructions that insurance companies compute a contract premium margin valuation for each of its lines where SFAS 60 or SFAS 97 applied (Becker, 1998, p. 222).

${ }^{17}$ SFAS 97 , SFAS 120 , SOP 95-1.

${ }^{18}$ Upton (1997).
} 
Standards Board (hereinafter "AASB") as AASB 1038 in 1998. First, insurance contract assets are measured at market value. Second, insurance contract liabilities are broken down into two components: the "best estimate liability" and the value of future profit margins. The best estimate liability is the amount expected on best estimate assumptions to be required to meet future benefits and expenses for the business in force at the valuation date. The calculation takes credit for future premiums and investment earnings. The future profit margins reflect service to be performed and are derived by assuming that the total expected profit when a policy is written emerges in relation to either single or multiple profit carriers. The effect is to spread profits over the lifetime of the contract.

Unlike FAS 60, where profits are recognised arbitrarily over the life of the business, under AASB 1038 insurance contract profits are recognised in relation to the performance of services and risk borne under the insurance policies in force. No profit is taken on the provision of advice in connection with sale or the initial administration related to setting up the contract. This constraint is imposed to help satisfy the principle that profit should not be recognised until both the service has been performed and the income to the company has been received. ${ }^{19}$ Thus a major innovation of Australian GAAP is the requirement to value policyholder liabilities using best estimate assumptions which are reviewed each year, rather than "locking-in" assumptions at issue (as in U.S. GAAP). Thus, profits reflect not only the planned margins but also the use of (changing) up-to-date assumptions, which is generally desirable although, contrary to fair value principles, the effect on profit, when assumptions are changed, is spread over the remaining lifetime of the policies concerned.

Canadian GAAP $^{20}$ (CICA, 2001) has taken some elements of the Australian GAAP, but also has some important distinctive features: in particular, it gives more emphasis to the recognition of profit at the point of sale. ${ }^{21}$ Asset values are calculated by "smoothed" market values. For both statutory solvency control and financial reporting purposes, actuarial liabilities are calculated using the "policy premium method" or PPM. This means calculating the present value of liabilities paid to policyholders, and expenses, and subtracting the values of premiums payable in the future (i.e. these being "gross premium", the premiums actually payable, including expense loadings). Appropriate assumptions are made about the early lapse and surrender of policies, plus a limited and reasonable margin or provision for adverse deviations between assumed and estimated business experience. Any profit in excess of that required to cover the provision for adverse deviations is reported as profit at the time of contract issuance.

Generally, this means that profits are recognised at the point of sale to a much greater degree than any other method described above. Unlike U.S. GAAP, actuarial assumptions of future expenses and mortality rates under Canadian GAAP can be changed at each valuation date. Such flexibility avoids the lock-in assumption

\footnotetext{
${ }^{19}$ Cant and French (1993).

${ }^{20}$ CICA (2001).

21 Adams and Scott (1994).
} 
problems of U.S. GAAP. It also differs from Australian GAAP because it neither allows for upfront profits, nor does it allow for the market valuation of assets.

Perhaps the most controversial GAAP practices occur in the U.K. Klumpes ${ }^{22}$ reviewed the lengthy debate on how to account for life insurance contracts. More recently the problems at Equitable Life ${ }^{23}$ led to further efforts to reform practices in relation to with-profit policies. Currently, life insurers must comply with a statement of recommended practice. $^{24}$ This contains only limited changes from SAP described above, and therefore arguably fails to present a realistic picture of an insurer's financial position.

In the absence of any authoritative GAAP in the U.K., major life insurers, keen to ensure that their shareholders appreciate the value of the business, therefore also report the "embedded value" of their business, generally reported as supplementary information, although the banks that own life insurers use this approach in the accounts of the banks (i.e. as holding companies). The method was originally developed by a committee established by the Association of British Insurers ${ }^{25}$ and subsequently issued as a guidance note, although it has never been formally endorsed as U.K. GAAP.

The embedded value approach is similar to Australian GAAP and is determined using actuarial calculations. ${ }^{26} \mathrm{~A}$ life insurer firstly projects the cash flows expected to arise in the future from the contracts in force at the balance sheet date. The life insurer uses "best estimate" assumptions on rates of future investment return, mortality, expenses, etc. From these projections it determines the amount expected to be transferred to the shareholders in each future year taking into account the need to retain adequate amounts in the fund to meet possible adverse contingencies. The stream of future transfers to shareholders is then discounted back to the balance sheet date at a discount rate that reflects the risks being run, that is, incorporating a risk premium above the risk-free rate of return. The embedded value is that discounted sum; the increase in this from one year to the next, plus the amount actually transferred to shareholders, is the embedded value profit, sometimes known as the "achieved profit".

When a new policy is written, its contribution to embedded value is the whole of the expected profit throughout the lifetime of the policy, discounted. This is a major difference from Australian GAAP, since this approach results in significant upfront profits. It aims to be "realistic" and uses market values of assets. However, the need to hold back reserves to meet regulatory solvency requirements is taken into account in the projections. Future assumptions are updated and the effect of changes capitalised.

\footnotetext{
22 Klumpes (1999).

${ }^{23}$ Penrose (2004).

${ }^{24}$ Association of British Insurers (2003). In addition, major writers of with-profits life business now report on a new "realistic" basis introduced in response to the problems at Equitable Life, although in our later analysis we focus on a more general version of SAP on traditional lines, and GAAP using embedded values.

${ }^{25}$ Association of British Insurers (1998).

${ }^{26}$ O'Brien (1994).
} 
However, the ASB has not been prepared to approve use of the embedded value method in insurers' accounts, other than as supplementary information. ${ }^{27}$ The ASB has not officially explained this. However, one large insurer recently ceased using the embedded value to "... ensure consistency with other industries". ${ }^{28}$ We therefore surmise that the upfronting of profits as permitted by embedded value is inconsistent both with other national GAAP reviewed above, and when compared elsewhere, for example, the spreading of profit on long-term contracts that arises under SSAP9 (Accounting for Stocks and Long-term Contracts).

\section{Insurance valuation principles}

Harrington $^{29}$ provides a conceptual overview of insurance accounting. In this section we follow Harrington's framework to provide an overview of basic general insurance accounting rules and identify some alternative income measures to help interpret financial results and to understand how they can change depending upon these assumptions. We first define the concept of profitability under both statutory and accounting (IFRS 4 acceptable - GAAP). If a few simplifying assumptions are made and arcane factors such as deferred income taxes are ignored, the major measures of profitability can be made fairly clear. We begin with the standard definition of SAP and U.K. GAAP. We then derive an economic profit measure which is equivalent to IFRS. Finally, we discuss the issue of how solvency affects the calculation with Solvency II.

\section{SAP and U.K. GAAP}

Insurance company annual returns that must be filed with the U.K. Financial Services Authority are prepared using statutory principles as set out in the U.K. Statement of Recommended Practice (SORP). The principles tend to be more conservative than GAAP in that income and surplus tend to be less than income calculated using GAAP. A major difference between SAP and GAP is the treatment of acquisition expenses, those incurred in selling and issuing insurance contracts. SAP requires that acquisition expenses be charged against income and surplus when incurred. GAAP requires that revenues and expense be matched, which means expenses are deferred compared with SAP.

Two important concepts in both SAP and GAAP accounting are earned premiums, EP, and incurred losses or claims paid, IL. Premiums are written when the policy is

\footnotetext{
${ }^{27}$ The U.K. Accounting Standards Board has not given its approval to U.K. GAAP as described here (the "achieved profits" method); many companies therefore prepare their accounts using a modified version of SAP and report their "achieved profits" as supplementary information. Instead, in July 2004 the ASB issued Exposure Draft 34 for life insurance (subsequently issued in 2005 as FRS 27), excludes from the definition of embedded value any valuable attributable to future investment margins and management fees in excess of their fair value (para. 22). Nevertheless the term "U.K. GAAP" is used to provide consistency with other national GAAP.

${ }^{28}$ Royal and Sun Alliance (2004).

${ }^{29}$ Harrington (1990).
} 
issued and the premium becomes payable. Premiums are earned evenly over the duration of the policy period. A principal liability of life insurers is their unearned premium reserve, $U P R$, which reflects the amount of written premiums, $W P$, that have yet to be earned as of the statement date. The relationship between these items in a given year is given by $E P=W P-\triangle U P R$. If earned and written premiums are equal during a year, $U P R$ does not change.

Incurred losses are defined as losses paid, LP, plus the change in the insurer's second major liability, the loss reserve, $L R: I L=L P+\Delta L R$. The loss reserve and/or fund for future appropriations is the estimated liability for all unpaid claims that have occurred as of the statement date. Since future claim payments traditionally have not been discounted, the book value of the liability, if accurately estimated, overstates its market value. Moreover, incurred losses for a given calendar year will be affected by revisions in reserves for previous years' claims to reflect new information about expected total claims. That is, increases in the loss reserve in year $t$ for claims that occurred in year $t-n$ will affect reported incurred losses in year $t$.

SAP surplus, $S$, is given by the basic accounting identity:

$$
S=A-L R U-P R,
$$

where $A$ is the SAP value of assets, which reflects bonds at amortised (book) value and common stocks at market value. The change in surplus during a given period can be written:

$$
\Delta S=\Delta A-\Delta L R-\Delta U P R
$$

The change in SAP assets equals premiums written less losses paid, underwriting and/or administration expenses, $E$, policyholder dividends, $D$ and income taxes, $T$, plus total investment gains, $I G$. Substituting for $\Delta A$ inEq. (2) and using $\triangle U P R=W P-E R$ and $\triangle L R=I L-L P$ gives:

$$
\Delta S=(E P-I L-E-D)-T+I G .
$$

The first four terms total SAP underwriting income. $I G$ has three components: net investment income, $I$, which consists of interest (including changes in the book value of bonds due to amortisation), dividends and rents, less investment and administration expenses; realised capital gains or losses on stocks and bonds, RCG; and unrealised capital gains or losses on common stocks, URCG. A popular measure of income is retax operating income, which is defined as SAP premium income plus $I$; after-tax operating income deducts $T$.

The principal modification of SAP surplus to obtain GAAP surplus involves creating an asset account to reflect prepaid acquisition expenses. Assuming that all policy administration expenses are acquisition expenses gives the following definition of surplus adjusted for prepaid expenses $(S A)$ :

$$
S A=A+(E / W P) U P R-L R U P R,
$$


where $E / W P$, the underwriting expense ratio, is assumed to be constant from year to year. This treatment essentially adds to SAP surplus the amount of the unearned premium reserve being held for acquisition expenses associated with the remainder of the policy period that have already been paid. Using the definition of $\triangle A, \Delta L R$ and $\triangle U P R$ gives the following expression for the change in adjusted surplus:

$$
\Delta S A=[E P-I L-(E / W P) E P-D]-T+I G
$$

Pretax GAAP underwriting income is given by the first four terms of this expression. As noted, the difference between GAAP and SAP operating income is that GAAP automatically matches expenses with revenues as premiums are earned.

The most common summary measure of underwriting profit is the combined ratio, $C R$, either before or after policyholder dividends. If after dividends it is defined as the sum of the ratio of incurred losses and dividends to earned premiums plus the ratio of administration expenses to written premiums:

$$
C R=(I L+D) / E P+E / W P
$$

One minus the combined ratio gives the pretax GAAP underwriting margin relative to earned premiums: $(1-C R) E P=[E P-I L-(E / W P) E P-D]$. The pretax GAAP operating margin including net investment income is given by $(1-C R)+I / E P$.

Another measure of income that analysts have looked to in recent years is the operating ratio, which is defined as:

$$
O R=C R-a(I+R C G) / E P,
$$

where $a$ is the amount of net investment income plus realised capital gains that is allocated to insurance operations (or for results by line, to a given line of business) as opposed to surplus. Thus the operating ratio equals the combined ratio minus the ratio of investment income allocated to a line to earned premiums for the line. The operating ratio differs from the pretax GAAP operating margin in that it reflects realised capital gains, and only net investment income and realised capital gains allocated to operations are included. If the operating ratio for all lines of business were equal to 1, a pretax increase in adjusted surplus would equal all unrealised capital gains plus the share of net investment income and realised capital gains allocated to surplus. A ratio greater than 1 indicates that the increase in adjusted surplus would be less than this amount.

The operating ratio essentially measures profit from insurance operations under the assumption that net investment income and realised capital gains on surplus plus all unrealised capital gains should be credited to owners. Critics have however argued that all capital gains should be included when assessing the profitability of life insurance operations. Does the operating ratio provide a good measure of whether life insurance operations in any year or over time even if one assumes that the underlying assumption about investment gains is appropriate? 


\section{Towards IFRS}

A major feature of IFRS is the absence of any conceptual discussion of measurement. The IASB and FASB recently initiated a project on the appropriate basis for measurement in financial reporting. The main objective of reporting is to provide decision-useful information to investors. The alternative measurement bases that are being considered are fair value, and value in use. Absent fair value, the major problem with both SAP and GAAP is that managers opportunistically exercise discretion in estimating reserve losses. Investors also appear to place different valuation weights than theory suggests. This raises the question of whether fair value is more relevant and reliable to be of use for estimating cost of capital for general insurers. Relevant considerations include which real-world economic assumptions are most relevant to assessing the profitability of life insurance firms, and what book measures arising from these assessments are most salient in informing cost of capital estimates? The current IFRS 4 (effective 2006) does not give specific guidance and a further Phase II project (incomplete) is intended to provide more clarification on the fair value basis for reporting.

Theory suggests that break-even premiums would equal the risk-adjusted present value of expected future claim payments plus the present value of all other cost of writing the business, including income taxes or foregone investment returns reducing from cost-reducing tax avoidance. Even if all policies were priced to break even, loss forecasts were perfectly accurate, and investment returns including capital gains were equal to the rate used to discount future costs, the fair value IFRS operating ratio generally would not equal 1 . The principal reason is the failure to discount losses in standard insurance accounting (including both SAP and GAAP). Lack of discounting is one major reason that standard accounting profits may differ greatly from economic profits. Another factor is the use of book values rather than market values for bonds.

To illustrate how IFRS might be reported in a way which is more consistent with an economic profit basis of performance measurement, let the market value for an insurer's surplus for all business written (old and new) be $S M$, defined as:

$$
S M=A+B P V L
$$

where $A$ is the SAP value of assets, $B$ is the market value of bonds less book value, and $P V L$ is the market value of unpaid claims, that is, the present value of unpaid claims discounted at a market-determined rate of interest. The change in $S M$ is:

$$
\Delta S M=[W P-(L P+D P V L)-E-D]-T+I G^{\prime},
$$

where $I G^{\prime}=I G+D B$, that is, net investment income plus realised and unrealised capital gains on bonds (incl. excess of bond amortisation) and on stocks. An expression for $\triangle S M$ that is more comparable to Eqs. (3) and (5) can be obtained by defining PVL as the present value of unpaid claims only for incidents that have occurred by the statement date and by noting that the unearned premium reserve less the adjustment for prepaid acquisition expenses would approximately equal the present value of 
unpaid losses for claims that are expected to occur after the statement date for policies written as of the statement date. Using these results gives

$$
\Delta S M=\left[E P-\left(L P+D P V L^{\prime}\right)-(E / W P) E P-D\right]-T+I G^{\prime}
$$

The quantity in square brackets equals U.K. GAAP underwriting profit using discounted losses.

\section{Towards Solvency II}

The above estimates of profits are based on fair value accounting, consistent with IFRS proposed. However under Solvency II, the profits are likely to be affected also by the projected future losses in both a market consistent way and also by the use of a standard discount rate for liabilities. In this case we incorporate flexible, rather than deterministic discount rates, and allow for flexibility in interpretation of accounts. We discuss these issues below.

\section{The IASB's proposals}

The discussion of insurance GAAP highlights considerable diversity in national practices. Given the global significance of the insurance industry in the transformation of risk, these variations pose an important challenge to the ongoing development of global accounting standards. In April 1997 the former IASC began to address this issue by appointing an Insurance Committee of the International Accounting Standards Board (hereinafter "Steering Committee"). Its purpose was to develop uniform international GAAP which is intended to achieve acceptance by the stock markets, national accounting standard-setters and the international insurance industry.

Subsequently the Steering Committee published an "Issues Paper" in November 1999. This set out some preliminary views on what could be a suitable way forward, but its review of current practice showed ongoing diversity in international accounting practices of life insurance firms, with no current practice meeting what the Committee envisaged as the way ahead. The Steering Committee was also conscious of the broader debate taking place on the valuation of financial instruments, and therefore worked on the assumption that IAS39, Financial Instruments: Recognition and Measurement, would be replaced by a new standard requiring full fair value accounting for the substantial majority of financial assets and liabilities. On this basis the Steering Committee believed that portfolios of insurance contracts should also be valued at fair value. ${ }^{30}$ However, it also recognised that determining the fair

\footnotetext{
${ }^{30}$ This assertion is controversial. Prior research has demonstrated the importance of measuring both financial assets and liabilities consistently at fair value (Linsmeier et al., 1998). However it has not conclusively demonstrated whether fair-value disclosures are value relevant for market-to-historical-cost book ratios in the property casualty industry (Petroni and Wahlen, 1995); the U.S. life insurance industry (Michel, 1999) or the U.K. life insurance industry (Horton and Macve, 1999).
} 
value of insurance liabilities on an actuarially objective and verifiable basis poses difficult conceptual and practical issues, given that there is generally no liquid, active secondary market in the liabilities arising from most types of insurance contracts.

The Issues Paper generated a large number of responses, with a debate over whether fair value was an appropriate way forward and, if it was, what fair value meant in this context. This was followed by the Steering Committee preparing a Draft Statement of Principles (DSOP), published (though not completed) on the IASB website. ${ }^{31}$ The DSOP indicated that, if IAS39 changed so that non-insurance financial instruments were to be measured at fair value, then fair value should also apply to assets and liabilities arising from insurance contracts. If there was to be no such change to IAS39, then entity-specific value should apply to insurance, though, in practice, this was expected to produce results very similar to fair value.

The Steering Committee rejected the deferral-and-matching approach used in existing G4 GAAP, that is, deferring income and expenses so that they can be matched against each other, on the grounds that it is inconsistent with a fair value accounting model. It also rejected the implicit or "deductive" methodology under which the value of liabilities is calculated by subtracting the surplus emerging from insurance contracts from the market value of assets. This deductive approach has a problem in that the surplus emerging is typically assessed using a projection of future financial conditions without reference to the full potential impact of options and guarantees as would be incorporated in a market-consistent valuation of financial instruments. In the absence of consistency the valuation of assets and liabilities on such an approach is problematic. ${ }^{32}$ Reitano $^{33}$ and Doll et al. ${ }^{34}$ propose an alternative asset-liability solution for addressing these problems under IFRS, which is presented as "explicit" or constructive - evaluating liabilities directly as one values assets. ${ }^{35}$ The Steering Committee ${ }^{36}$ considers the explicit approach to be superior to an implicit approach, and cites the consistency with recently issued IASB standards on provisions (IAS 37) and pensions (IAS 19). The constructive methodology defines the market value of liabilities based upon an analogy to assets, that is, value the liability as if it were a contingent form of fixed income security by using option pricing techniques.

When viewed from a constructive perspective, a life insurance contract is simply an investment whereby for a given price (single or periodic payments), the insurance firm agrees to pay given amounts based on the realisation of certain contingencies.

31 www.iasb.org.uk.

32 The IASB's tentative conclusion for Phase II is that unless there is market evidence to the contrary, fair value would have to be assessed on the basis of current prices of insurance products. The latter approach may lead to some odd results; for example, if an insurer raises its prices with a view to increasing its profits, it may mean it has to increase its provisions, with profits perhaps decreasing. Hence, insurers have an incentive to find the relevant market evidence. Our calculations, therefore, assume that liabilities are not based on current insurance prices.

${ }^{33}$ Reitano (1995).

${ }^{34}$ Doll et al. (1998).

${ }^{35}$ Doll et al. (1998) discuss a number of methodologies which can be used to implement a constructive approach to the fair valuation of life insurance firm liabilities.

36 Para. 199, Issue 6B. 
In addition to this basic structure, policyholders have certain financial options which they can exercise, for example to surrender the policy before the contractual termination date.

The constructive method has the advantage of reflecting the presence of embedded options in the value of the liability. This requires a number of assumptions to be made in valuing the liability which are not currently required by G4 GAAP. Furthermore, deferral of acquisition costs would no longer be allowed; credit for the margins backing DAC is embedded in this market value of the liability and its amortisation is implicit.

\section{Evaluating alternative GAAP}

We now show how international diversity in G4 GAAP differentially affects the pattern and distribution of profits earned over the term of a simple life insurance contract. We will illustrate this by referring to an illustrative simulation of life insurance accounting for a straightforward life insurance endowment contract, with the sum insured payable after 20 years. This analysis leads to a discussion of the major difficulties associated with IFRS and motivates the development of a broader conceptual framework that can be applied to analyse the fair valuation of more complex insurance contracts.

The pattern of emergence of profits, liabilities and retained surplus over the life-time of a simple life insurance contract is now demonstrated by using a simulated life profit testing model developed by Klumpes. ${ }^{37}$ The model is stripped of much real-world complexity in order to reveal basic concepts and principles.

Assume a world where the riskless interest rate is 8.5 per cent p.a., now and in the future. The analysis focuses on a basic pure endowment contract in which annual premiums are required to be paid over a term of 20 years in order to obtain $\$ 8,000$ at the end of this period. There is no mortality risk in this simplified example, and we also assume no surrenders.

First we calculate the annual premium payable at the beginning of each year, without any loading for expense or profit (the "net premium"). This is derived from:

$$
P(1+r)=\frac{r s}{(1+r)^{n}-1}
$$

where $P$ is the annual premium, $r$ is the interest rate, $s$ is the sum assured and $n$ is the term. Applying this formula to the above facts, the net premium to be paid is $\$ 152.41$ per annum.

We now extend the example to include a loading for initial and renewal expenses and profit. A premium $\left(P^{t}\right)$ that includes a loading for renewal $(E)$ and initial $(I)$ expenses and profit $(X)$ is normally referred to as an office premium. The formula for

\footnotetext{
${ }^{37}$ Klumpes (1999).
} 
calculating the office premium is as follows:

$$
P^{t}=\frac{P}{1-(E+X)-\frac{I}{1-\left[\frac{1}{1+r}\right]^{n} / 1-\left[\frac{1}{1+r}\right]}} .
$$

Assuming that the net premium is calculated as above, the interest rate $r=8.5$ per cent, the sum assured is $\$ 8,000$, the term $n$ is 20 years, $I=75$ per cent of office premium, $E=2.5$ per cent of office premium, and profit loading $P=6$ per cent of each office premium, then the office premium $P^{t}$ is calculated as $\$ 178.90$. We assume that, each year, the premium less expenses is invested in a risk-free zero-coupon bond redeemable at a price of 1.00 on the maturity date of the contract. We have assumed no early terminations.

We then calculate year-by-year, the assets and liabilities relating to the contract, valued in accordance with SAP, the four GAAPs discussed, and IFRS and/or Solvency II. ${ }^{38}$ These different methods produce various answers for the liabilities, depending on the relevant standard. The assets are in each case the value of the bonds bought by the premiums paid to date plus, in the case of U.K. GAAP, the embedded value. In each case profit is the increase in the excess of assets over liabilities.

Then various patterns of profit over a 20-year contract emerge. Table 2 shows the assets, liabilities and profit over the life of the contract under the various methodologies. We show the difference in the pattern of profit emergence in two ways. First, Table 2, Panel A, shows the position if interest values are constant at 10 per cent. This is compliant with a deterministic assumption as required by IFRS 4. Second, Table 2, Panel B shows the position with varying interest rates, as permitted under Solvency II, and in this case using the rates in U.K. government bonds over 1990-2008.

SAP was not primarily developed for general purpose financial reporting. Acquisition costs are fully expensed at the outset, and we have a prudent valuation of the liabilities in accordance with solvency rules. The outcome is a heavy loss upfront and slow emergence of profit.

G4 GAAP typically requires less conservative actuarial assumptions than the SAP, producing an earnings emergence profile showing earnings earlier than under SAP. The total profit emerging over the life of the endowment contract is necessarily identical, but it is interesting to analyse how the pattern and volatility of profits emerging over time varies across different GAAPs. This reflects the different GAAP rules, which also respond in different ways to changing interest rates.

Of the national GAAPs, U.S. GAAP produces the lowest upfront profit. U.S. GAAP has rules designed to spread profit over the lifetime of the contract, and the

\footnotetext{
${ }^{38}$ We restrict the scope of our discussion in this section to measurement principles that are already codified by standards already issued by the IASB in the related topics of financial instruments (IAS 39) and provisions (IAS 37). There are however a number of other open issues that can bear on fair value measurement, such as assumptions about management performance, credit standing and treatment of deferred acquisition costs.
} 
Paul J.M. Klumpes et al.

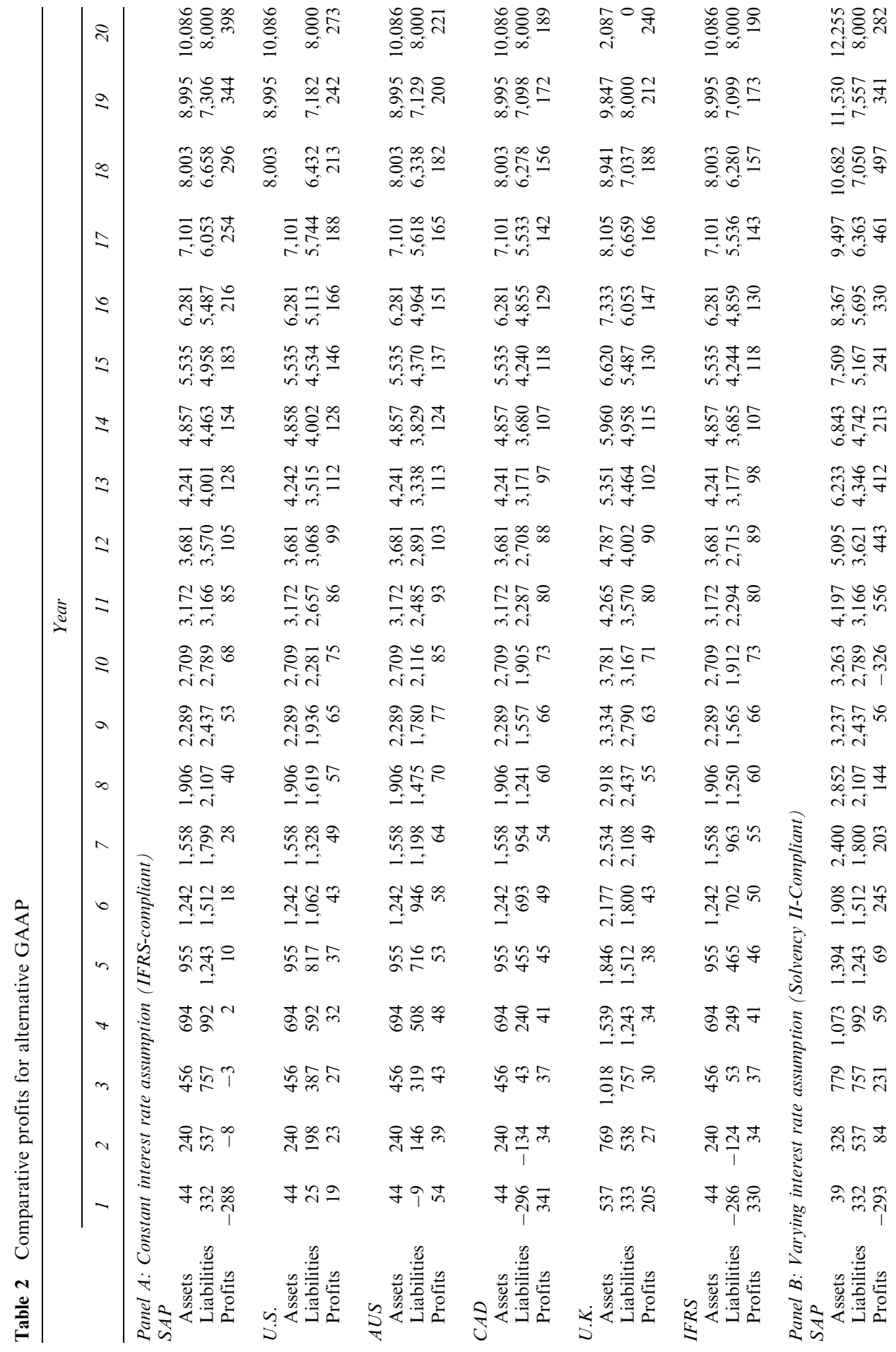




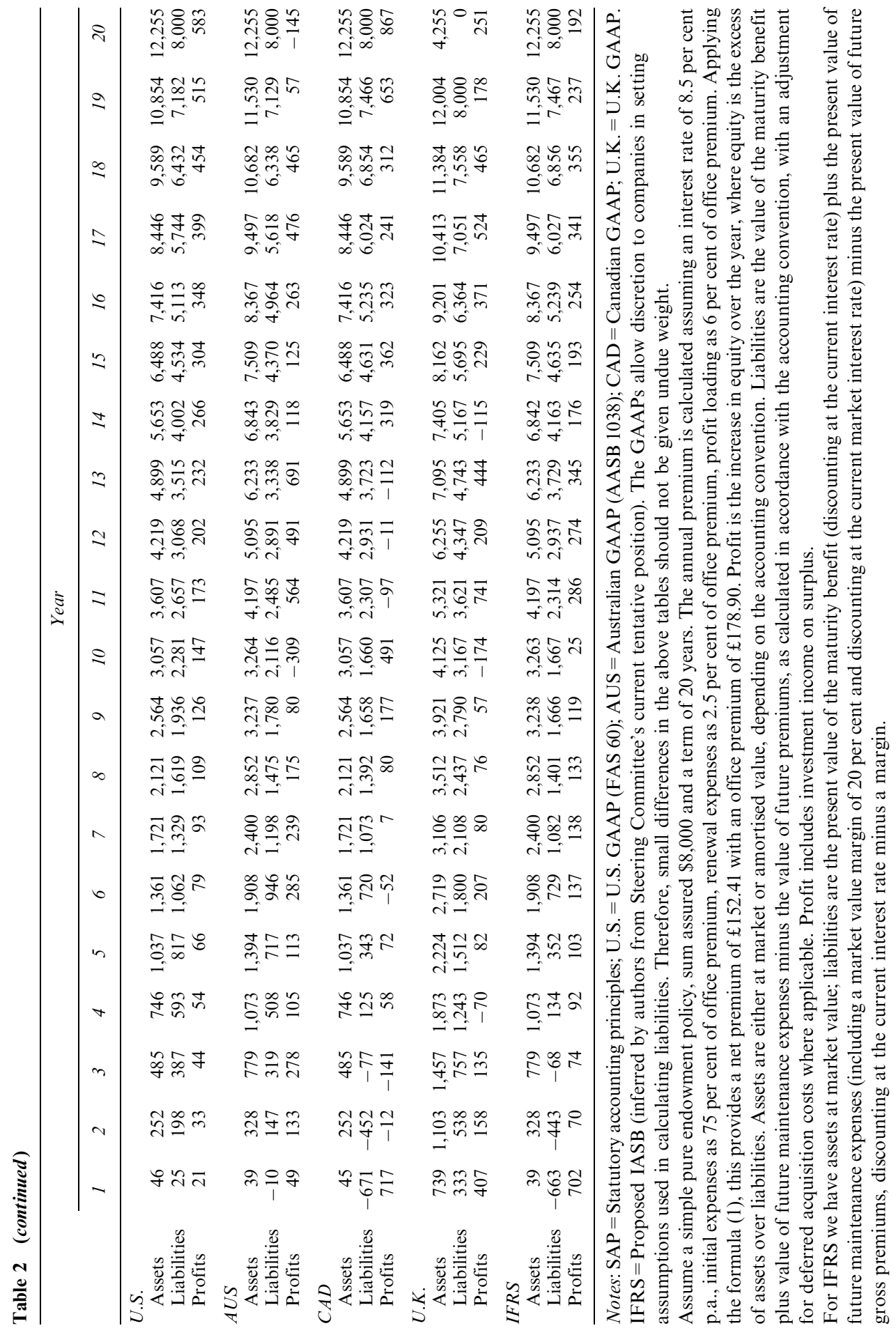


lock-in of assumptions also contributes to a relative insensitivity of changing interest rates.

Australian GAAP also produces a relatively smooth profit profile. This reflects the prohibition of profits emerging on the sale of the policy, and the way in which the effect of changes in conditions is spread over the remaining lifetime of the contract.

Canadian GAAP has profits that are high upfront as a result of capitalisation of the margins expected to accrue from all premiums payable. The results are then sensitive to changes in conditions.

U.K. GAAP also shows high profits at the outset, the result of including the embedded value as an asset. The fact that a risk discount rate is applied to expected future surpluses reduces the initial profits somewhat.

Both Australian GAAP and Canadian GAAP attempt to serve both regulatory and shareholder perspective users by providing a universal and consistent set of realistic profit reporting. By contrast, both U.K. GAAP and U.S. GAAP maintain different accounting principles. This leads to the question of whether a single set of realistic statements or two sets of accounting principles is more appropriate for users.

IFRS differs from SAP and national GAAP by using fair valuation of assets and liabilities and not permitting DAC and/or accruals. Thus the pattern of net profit evolves in accordance with changes in the interest rate environment (in this example, not fully hedged). It should be noted that, while the example is stylised, the pattern of profit emergence is extremely sensitive to gains or losses. Since the impact of these variances are reported in the current period (rather than deferred), management is arguably in a better position to understand how the value of the business is changing and adjust its decisions accordingly. ${ }^{39}$ This issue is highlighted by the consistently higher profits attributable to Solvency II-compliant varying interest rate simulations (Panel $\mathrm{B}$ ), relative to IFRS-compliant, deterministic interest rate simulations (Panel A).

A major weakness of IFRS is the difficulty of judgmentally determining the relationship between the risk spread and the feasible cash flow assumed. Insurance contracts fail to meet the criteria for classical financial model building, particularly the assumption of arbitrage-free markets. ${ }^{40}$ By contrast, the main strength of standard cash flow actuarial techniques, as endorsed by existing G4 GAAP, is that they are based upon well-established actuarial techniques, and provide a linkage to actuarial pricing methodology. The downside is potential inconsistency with market conditions. IFRS, by way of contrast, focuses directly on valuing the liabilities, in a marketconsistent way. This is theoretically sound and comprehensive, given its focus upon cash flow. The fair valuation of liabilities can be developed independently of the underlying asset portfolio, and is thus potentially volatile. This can be viewed as either a strength or weakness. Since its volatility prevents a smooth progression of value, some would regard it as a weakness. To the extent that fair valuation of liabilities is

\footnotetext{
${ }^{39}$ Wallace (2002).

${ }^{40}$ Albrecht (1994).
} 
216

intended to depict more accurately the financial position and performance of the company, it is a strength. ${ }^{41}$

The constructive methodology underlying IFRS is, however, complex and unfamiliar to most industry accountants and actuaries. Any attempt to standardise the underlying assumptions regarding mortality, profits and surrender behaviour would defeat the objective of establishing a "fair value". These estimates must take into account product and company specifics to capture fair value, but it is, of course, the market's estimates of the impact of these factors which is reflected in fair value. In the next section we provide a more general conceptual framework for fair value accounting, in order to evaluate some unresolved problems with the IASB fair value proposals and identify possible solutions in the form of new risk disclosures. This accounts for the realistic complexities invoking hybrid insurance contracts that are potentially subject to IFRS 4 .

\section{Unresolved issues in fair valuation}

The comprehensive Solvency II framework that models expected future cash flows related to various types of life insurance contract requires that a consistent valuation methodology be employed across various components of life insurance contracts. However, the IASB's latest Discussion Paper $^{42}$ raises a number of unresolved measurement issues associated with any effort to explicitly estimate the fair value of life insurance contracts under a more comprehensive IFRS. These issues were also discussed within the context of financial instruments by a subsequent discussion paper issued by the Joint Working Group of the $\mathrm{G} 4+1 .{ }^{43}$

Solvency II also highlights the potential role for additional risk disclosures as a solution to resolving such uncertainties. Yet unlike banks, life insurance firms currently provide very few disclosures about the explicit and implicit risk exposures involved in the management of their contracts. ${ }^{44}$ This perhaps reflects the lack of a coherent conceptual framework, to date, for insurance accounting, to which systematic risk disclosures could be applied along the lines of those required by IFRS 4 .

We now briefly discuss the implication of this framework in resolving a number of major contentious issues covered under general issue 11 of the Issues Paper. ${ }^{45}$ Table 3 summarises each of these six issues and outlines our associated proposals for enhanced risk-related reporting.

${ }^{41}$ Doll et al. (1998, p. 64).

${ }^{42}$ IASB Discussion Paper (2007).

43 Joint Working Group (2001).

${ }^{44}$ Multidisciplinary Working Group on Enhanced Disclosure (2001).

${ }^{45}$ Whether the option has any value at expiration depends on the asset's future value by actuarial profit measures. Pindyck (1988) illustrates the potential importance of valuable investment options for the value of the firm. This analysis presumes that imperfections exist in life insurance which are understated by the book value of assets (Penman, 1996; Klumpes and Shackleton, 2000). 
Table 3 Unresolved issues in fair valuation of life insurance contracts

\begin{tabular}{ll}
\hline Unresolved issue $\quad$ Problem & $\begin{array}{l}\text { Proposed risk disclosure (in italics if } \\
\text { within IFRS4) }\end{array}$
\end{tabular}

11A. Are life insurance contracts financial instruments?

11B. Is fair value appropriate to life insurance contracts?

11C. What should be general approach to calculating fair values of uncertain liabilities?
Life insurance contracts include

a "servicing" element

There is a need to understand credit risk and liquidity risk

No deep liquid market

Intangibles incorporate the market price of risk

Expected events underlying individual business lines may differ from probable events affecting individual contracts

Is it a payment to a third party or to policyholders?
Disclose separately the "embedded value"

(a) Disclose credit risk

(b) Disclose liquidity risk

(a) Disclose results of deterministic stress tests

(b) Comment on model risk

(c) Assume 100 per cent certain obligations to policyholders and compare result assuming some specified credit rating

(d) Show SAP result and minimum capital requirement

Show VAR or other appropriate risk measure

Disclose scenario tests of the sensitivity of insurance liabilities to alternative interest rate exposures

Disclose separately the "best estimate" and market value margins

\section{Are insurance contracts financial instruments?}

Question 1 of the IASB's Discussion Paper ${ }^{46}$ asks whether insurance contracts are financial instruments. One fundamental issue in the debate on an international standard for insurance contracts has been whether to regard them as financial instruments or as service contracts. If the former, it is logical to base the accounting for insurance contracts upon IAS 39. If the latter, then the contents of IAS 18 ("Revenue") appear more relevant. In essence, an insurance contract has elements of both. Viewing insurance as a service contract is more likely to lead to a smooth pattern of profit recognition consistent with profits reflecting performance over time. On the other hand, treatment as a financial instrument could, on certain assumptions, lead to significant profits being recognised at the outset of the contract. The diversity in current approaches illustrates the range of possible solutions.

\footnotetext{
${ }^{46}$ IASB Discussion Paper (2007), para. 30.
} 
The 1999 Steering Committee viewed that many types of contracts have features of financial instruments, although it acknowledges that they also have non-financial attributes. ${ }^{47}$ However there are a number of problems associated with estimating the fair value of life insurance firm liabilities, especially since the majority are not actively traded in a deep and liquid market. This is one reason why insurance contracts have been exempted from the requirements for fair valuation of financial instruments in other standards. ${ }^{48}$ For example, in the absence of a deep and liquid market for insurance liabilities, it is thought that liabilities would have to be valued by making a discounted "best estimate" of expected future cash flows and adding a "market value margin" to reflect the premium required by the margin to assume the risk. ${ }^{49}$ However, in addition to problems in determining these best estimates, how is the market value margin calculated, and should it ignore risk on the grounds that the market would not reward such risk-taking? An example of a difficulty in life insurance contracts is how to assess a market-consistent value when policies lead to cash flows 20 or more years into the future, where finding other financial instruments of this term from which to deduce fair values can be well nigh impossible.

The approach taken under U.K. GAAP is to use embedded value but the IASC Issues Paper did not favour this. They felt that liabilities should be measured appropriately rather than add an embedded value asset to the balance sheet to correct an inappropriate valuation of liabilities (para. 643). They also referred to a number of arguments, such as the contention that the embedded value does not meet the definition of an asset: it is not a resource controlled by the insurer as the policyholder is not obliged to continue the policy. Nevertheless, there is a strong argument that embedded value information is relevant and useful to users of accounts, as an indication of the potential profit from current business, albeit subject to a number of risks. Shareholders using embedded value information have to appreciate that the value is sensitive to changes in assumptions, such as future investment returns, and especially that the use of deterministic assumptions may lead to under-valuation of options and hence over-statement of the value to shareholders. In principle this can be counter-acted by increasing the risk discount rate applied to future surpluses, but this is difficult as there is no objective method of assessing what is a suitable risk discount rate.

We agree that inclusion of the embedded value in a firm's accounts is inappropriate. However, while accounting standards focus on assets controllable by an entity as a result of past events, the concept of "franchise value" proposed in our conceptual fair valuation framework suggests that there is merit in disclosing, as supplementary information, the embedded value, which provides useful additional information about expected future cash flows. If, therefore, a reliable approach to calculating embedded values can be determined, this would be helpful supplementary information for life insurance companies' accounts.

\footnotetext{
${ }^{47}$ Para. 537.

${ }^{48}$ For example, SFAS 133, IAS 39.

${ }^{49}$ Hairs et al. (2002).
} 


\section{Is fair value appropriate?}

Question 2 of the IASB's Discussion Paper ${ }^{50}$ asks whether the concept of fair value, as presently applied to financial instruments (IAS 39), is also appropriate to financial reporting of insurance activities. The Steering Committee asserted that consistency between the treatment of assets and liabilities of an insurance enterprise is of primary importance, and assumes that the IASB will adopt a comprehensive approach to reporting all financial instruments at fair value. ${ }^{51}$

Fair value gives more volatile results than other methods of measuring assets. This leads to concerns by insurers about reflecting the complexity of life insurance business. ${ }^{52}$ Because assets and liabilities often involve complex actuarial estimates of distant future events that frequently depend on the exercise of options written by insurers and held by policyholders. ${ }^{53}$ It is not easy to apply option pricing techniques as these options are often of longer duration than traded options, and depend on the behaviour of policyholders, for example, whether they will exercise guaranteed annuity options. A non-trivial degree of inaccuracy in the estimation of the value of these written options is therefore to be expected; yet such inaccuracy could have an enormous impact on the solvency risk of insurers.

It is therefore important that these risks be disclosed and understood within an overall fair value framework. The general conceptual framework explicitly accounts for the option to terminate life insurance business in the put option at the enterprise level. The contract-specific framework considers the impact of market risk associated with the various major classes of insurance contract. However, users of accounts also need to have an understanding of credit risks and liquidity risks in an insurer's assets. IFRS4 will require information about credit risk as if insurance contracts were within IAS32, which applies to non-insurance financial instruments.

Besides solvency risk, liquidity risk is often regarded as unimportant for life insurers: since as claims usually emerge over a long period, most of the policies are less liquid than their assets. ${ }^{54}$ However, there can be exceptions, for example, if the trustees of a large pension scheme wish to terminate their policy. There is therefore a case for disclosing liquidity risks.

\section{What should be the general approach to applying fair value?}

Question 5 of the Discussion Paper asks what should be the general approach in applying fair value to insurance contracts. It proposes a "current exit value" approach. By contrast, the Steering Committee recommended that the measurement approach described in IAS 37 provides a general model for estimating the fair value of most insurance obligations. IAS 37 (para. 37) defines a provision as the "amount that an enterprise would rationally pay to settle the obligation at the balance sheet date or

\footnotetext{
${ }^{50}$ IASB (2007) Discussion Paper, para. 119.

${ }^{51}$ IASB (2007) Discussion Paper, para. 557.

52 Dickinson and Liedtke (2004).

${ }^{53}$ Upton (1997) proposes that life insurance contracts can be viewed from an option pricing framework.

${ }^{54}$ Babbel and Santomero (1999, p. 312).
} 
to transfer it to a third party at that time". However this definition does not necessarily accord with an entity's own assumptions about future cash flows.

Moreover, there are a number of conceptual difficulties with relying on this definition of fair valuation. First, the going concern assumption means that a life insurer typically expects to extinguish its liabilities by paying the policyholder (together with payments of tax and expenses). So why is a transaction with a third party relevant, especially as capital markets to transfer the risk do not exist in practice? It may be argued that it is not strictly relevant or realistic, but that this is an indication of the value of the liability: but possibly not realistic.

Second, fair value implies using market estimates for future management expenses, which means taking credit for inefficient management, absent any judgment about stewardship. Finally, the fair valuation approach has greatest difficulty in measuring contracts in their early lifetime, since the liability is minimal. The problem is that there is no deep liquid market for insurance liabilities.

We emphasise that, although there are actuarial techniques for valuing liabilities, the development of models for market-consistent values is quite new. ${ }^{55} \mathrm{We}$ are therefore some way from having tried and tested models. This lack of practical experience of fair values is also a concern expressed by Dickinson. ${ }^{56}$

The conceptual fair valuation framework embedded in IFRS 4 is static in the sense that changes in firm valuation over time resulting from the effect of unexpected changes in the environment, as opposed to the effect of deliberate management actions to exercise control over the business, is not explicitly measured. It is therefore appropriate for life insurers to disclose the impact on the calculated liabilities of specific changes in conditions, such as a specified change in rates of interest or equity prices. However, this would need to be combined with the impact of such deterministic stress tests on the value of assets. It is also appropriate for life insurers to indicate the sensitivity of their results to potential changes in assumptions on mortality, persistency, etc., and indeed, where there actually are changes in such assumptions, to disclose the effect they have had. IFRS4 requires disclosure of the sensitivity of profit or loss and equity to changes in variables that have a material effect on them, which is a valuable development.

It can also be important for the reader of the accounts to understand what modelling has taken place in the calculation of liabilities, so that the model risk can be understood. The conceptual framework above also highlights the need to clearly separate the effect of external events on different components of life insurance firm value, since it is well known that adjusting liabilities for credit risk can produce counter-intuitive results. This is because the IASB's suggestion that fair value measurement of an insurance contract should reflect the credit characteristics of that contract $^{57}$ could have a strange effect on the firm's balance sheet. This is because a life insurance firm with a deteriorating financial position would see its liabilities reducing to reflect the lower probability of them being paid: this gives some offset to the

\footnotetext{
55 Sheldon and Smith (2004).

${ }^{56}$ Dickinson (2003).

${ }^{57}$ IASB (2004) IFRS 4, BC6 para. (c-iii).
} 
deterioration. ${ }^{58}$ If, therefore, fair value is to be used, it is important that the reader of the accounts understands the credit risk applying and the way in which this has influenced the results.

The Solvency II framework instead appears to assume that the insurer calculates the present value of liabilities on an assumption that the obligations to policyholders are satisfied with certainty, and to compare this with the fair value calculation allowing for credit risks, or perhaps some calculation made assuming some specified credit rating.

The concept of liquidation value in our conceptual framework also implies that separate disclosure is required, at least in summary terms, of the outcome of the statutory accounting principles for the insurer, and the extent to which the excess of assets over liabilities on such basis exceeds the minimum capital requirement set by the regulators (i.e. the market value of tangible assets). However, we also acknowledge that the robustness and consistency of this measure is likely in practice to be sensitive to the diversity of local regulatory requirements.

\section{Should the fair value of intangibles be included?}

Question 6 of the IASB Discussion Paper $^{59}$ (2007, para. 174) asks whether the fair value of an insurance contract should include the fair value of intangibles related to "policyholder behaviour", such as DAC. The Steering Committee argued that they should not be included as they do not represent the value of the financial assets or liabilities embodied in the insurance contract (para. 576). But what if the fair value of insurance business includes an element of "inherent goodwill" or market risk margins that is incorporated in third party's estimates to take over the business (or "franchise value")?

Perhaps the most difficult part of implementing any new accounting paradigm that incorporates these issues explicitly is the determination of the market price of risk. The DSOP requires that insurance contract liabilities include a provision for risk to be based on the market's price for that risk. However, there is very little evidence available to determine prices associated with the sale of blocks of business or reinsurance arrangements, since such transactions often do not meet the typical transaction cost constraints needed for the application of theories of financial economics. ${ }^{60}$ A further risk disclosure that might be helpful is the value at risk, although further work is needed to understand what is the appropriate way of interpreting this in the context of long-term insurers' liabilities. Value at risk measures the worst expected loss over a given time interval under normal market conditions at a given confidence level. ${ }^{61}$ A key issue is that the reader of the accounts needs to have some understanding of the impact of stochastic variations in parameters on the financial position of the life insurer.

\footnotetext{
58 Babbel (1997, p. 118).

${ }^{59}$ IASB (2007) Discussion Paper, para. 174.

${ }^{60}$ Babbel et al. (2002).

61 Jorion (1997).
} 
Moreover, such aggregate market risk measures are typically oriented towards short-term period exposures and assume normal loss distributions. They may thus provide little insight into the impact of risk management tools, such as diversification and pooling that ameliorate exposure to market risk over longer time periods where interest rate duration is problematic. ${ }^{62}$ Indeed, there are alternatives to using value at risk, for example the conditional tail expectation. Moreover, market risk differentially affects life insurance firms' assets and liabilities, and is likely to interact with other sources of risk, such as interest rate risk, credit risk and liquidity risk. ${ }^{63}$ Information about firms' operational risk and internal risk models used would also help clarify the overall risk position of the enterprise: such information is specifically required by the German Accounting Standard No. 5-20. ${ }^{64}$

\section{Unit of account}

Question 11 of the Discussion Paper ${ }^{65}$ asks whether the fair value of insurance contracts should be based on individual contracts or books of similar contracts. "Unit of account" refers to the level at which the accounting results are measured. This is an important concept because accounting orthodoxy requires that the accounts reflect "probable" events. For most insurance contracts, the "probable" event is no claim in any year - which might lead to the erroneous conclusion that there is no liability in respect of most insurance liabilities, whereas most actuaries consider "expected events" in terms of the application of probabilities in the future. ${ }^{66}$

The Steering Committee favours focusing on groups of insurance contracts that have substantially the same contractual terms. ${ }^{67}$ Should this be the amount which would need to be paid to a third party to take over the whole of the existing business? This is effectively the amount payable in a business combination. It would ordinarily be regarded as including a payment for goodwill, not meeting the requirement for recognition in financial statements.

The alternative would be to treat each contract separately. However, this will lead to inconsistencies between "probable" and "expected" events, since these concepts only converge if the "unit of account" is a portfolio of like contracts large enough for the law of large numbers to apply. ${ }^{68}$ This could have implications for considering what is the surrender value of a policy, or its value on the second-hand market (which does exist for a number of contract types). Indeed, why is the second-hand market not relevant? Surely this is an example of an active market. ${ }^{69}$ If we were to use the value in the active second-hand market where this exists, then it is clear that it would be

\footnotetext{
${ }^{62}$ Gutterman (2000).

${ }^{63}$ Babbel and Santomero (1999).

${ }^{64}$ German Accounting Standards Board (2000).

${ }^{65}$ IASB (2007) Discussion Paper, para. 233.

${ }^{66}$ McCrossan (2002).

${ }^{67}$ IASB (2007) Discussion Paper, para. 580.

${ }^{68}$ Idem.

${ }^{69}$ McGurk (1998).
} 
inconsistent, for other contracts, to use the value which would need to be paid to a third party if a "chunk" of the business were transferred.

Our approach to overcome this dilemma is to provide standardised disclosure of the outcomes of scenario tests that reflect the impact of external market forces, such as the force of interest, on the reported fair valuations. Gutterman ${ }^{70}$ suggests this could be achieved if either a discrete number of separately run alternative scenarios or a large number of stochastically generated scenarios are run, based on assumed statistical distributions or professional judgments as to expected future cash flow scenarios. Indeed the Canadian Institute of Actuaries recently required a series of prescribed scenarios which were considered sufficient to determine the interest rate risk provision for individual blocks of business. We have mentioned that IFRS4 will require new disclosures, and information about interest risk is specifically mentioned.

\section{How is the liability extinguished?}

Question 14 of the IASB Discussion Paper ${ }^{71}$ asks whether the fair value of insurance contracts should be estimated using an allowance for credit risk. It has been argued elsewhere by the IASB that own credit risk should be included in assessing the fair value of liabilities. However, by contrast, the Steering Committee favoured exit value, that is, the amount that the insurer would pay another enterprise to assume all of the risks. ${ }^{72}$ The Solvency II framework also implies that part of the value of an insurance contract incorporates an expectation that profits will emerge from future business (e.g. franchise value), as well as any exit price (e.g. default risk). ${ }^{73}$ Therefore, considerable care is needed to ensure that the values estimated for accounts do not include items such as the concept of "franchise value" that do not meet the recognition requirements.

However, the debate concerning credit risk is not over. IASB has the tentative conclusion for Phase II that entry values may be used if valid information about market values is not available. It remains to be seen what conclusion IASB reaches and why.

However, one approach that may help is if life insurers disclosed separately the "best estimate" of liabilities and the market value margins that have been added to obtain the calculated liability. Testing the feasibility of techniques to produce fair values is ongoing; it remains to be seen what the outcome is. A useful additional risk disclosure would be to compare the best estimate of the liability and the market value margin, thereby deriving the "exit price" of the business.

\section{Conclusion}

A major problem in producing a single set of internationally harmonised set of accounts for life insurance enterprises is the lack of consensus about how best to

\footnotetext{
${ }^{70}$ Gutterman (2000).

${ }^{71}$ IASB Discussion Paper (2007) para. 233.

${ }^{72}$ Idem (para. 597).

${ }^{73}$ Dullaway and Bice (2002).
} 
meaningfully describe the financial position today in respect of an insurance contract sold in the past that will involve payments in the future. In response to both economic and legal pressures in recent years, accounting standard setting bodies in G4 countries have developed GAAP which incorporate various methods for dealing with this issue, in order to serve both stewardship and valuation purposes. In contrast to the legalistic SAP method, existing matching-based G4 GAAP attempts to convey value-relevant information to capital market participants about the firm's future earnings that are expected to emerge from its existing business lines. However G4 GAAP also attempts, to some extent, to incorporate managements' subjective expectations as to the value of future profits based on existing business which have not been "earned".

The lack of any consistent method of objective risk-adjustment in G4 GAAP also leads to conceptual difficulties which may limit their reliability and comparability to investors. However this in turn raises significant unresolved issues in determining the "fair value" of insurance contracts. Since fair value liabilities change constantly because of changes in the discount rate and other assumption changes, traditional concepts of loss recognition, income smoothing and accounting practices that vary with product design are no longer applicable.

The existence of major, unresolved IASB accounting issues between existing matching-based G4 GAAP on the one hand, and the IASB asset-liability approach on the other, highlights the continuing difficulties underlying insurance accounting. The ongoing convergence, consolidation and globalisation of the financial services industry also raise unresolved issues concerning the consistency in measuring insurance contracts and financial instruments.

By contrast, the alternative fair value "constructive" method as proposed by the IASB is an evolving system, which focuses on assets and liabilities being measured consistently. Consistent with this proposal, the Solvency II provides a more model-based fair valuation framework, which potentially implies that there are various contingent assets and liabilities which should be additionally recognised on the balance sheet. Such an accounting valuation system is at odds with the traditional residual income valuation framework, since it is asset-liability-based, and thus does not provide for deferral and amortisation practices that enter into earnings multiple calculations, nor does it permit variation between book value and market value of various assets and liabilities. However we argue that this framework is both consistent with that proposed by the Steering Committee, and is likely to be appropriate to life insurance firms, especially given advances in financial risk management, the globalisation of capital markets, and the complexity of financial instruments in use today.

The Solvency II conceptual framework can facilitate the analysis of unresolved problems in fair valuation to financial reporting by identifying separate components of a consolidated balance sheet which incorporate various sources of credit, market and business risk associated with fair valuation principles. We also propose a series of risk disclosures to overcome exposures that can otherwise potentially lead to a mismatch between economic and accounting performance measurement of these various components of fair valuation. Some but not all of these disclosures are already included in IFRS4, which are generally limited to disclosures about amounts in 
financial statements and the amount, timing and uncertainty of future cash flows. By contrast, our recommendations for risk disclosure go further by identifying areas of risk allocation, for example, operational risk and information about internal risk models that are not generally covered by a fair value reporting system.

Further research is needed to address more comprehensively the performance aspects of the fair valuation reporting model, given the growing interest and concern about the international competitiveness and efficiency of life insurers. We therefore urge researchers and practitioners to continue a debate on resolving these outstanding issues in order to successfully develop a single harmonised set of international accounting standards.

\section{References}

Adams, M. and Scott, W.A. (1994) 'Realistic reporting of life insurance company policy liabilities and profits', Journal of the Institute of Actuaries 121: 441-458.

Albrecht, P. (1994) 'Financial approach to actuarial risks?' Proceedings of the 2nd AFIR International Colloquium 4: 227-247.

Association of British Insurers (1998) Exposure Draft: Guidance on Reporting Shareholders Profits from Long-Term Business in Group Accounts: The Achieved Profits Method, London: Association of British Insurers.

Association of British Insurers (2003) Statement of Recommended Practice on Accounting for Insurance Business, London: Association of British Insurers.

Australian Accounting Standards Board (1998) Statement No. 38. Financial Reporting of Life Insurance Business, Melbourne: Australian Accounting Standards Board.

Babbel, D.F. (1997) 'Comment on Doll et al.', in I.T. Vanderhoof and E.I. Altman (eds) The Fair Value of Insurance Liabilities, Boston: Kluwer.

Babbel, D.F. and Santomero, A.M. (1999) 'An analysis of the financial risk management process used by life insurers', in J.D. Cummins and A.M. Santomero (eds) Changes in the Life Insurance Industry: Efficiency, Technology and Risk Management, Boston: Kluwer.

Babbel, D.F., Gold, J. and Merrill, C.B. (2002) 'Fair value of liabilities; the financial economics perspective', North American Actuarial Journal 6(1): 12-27.

Becker, D.N. (1998) 'The value of the firm: The option adjusted value of distributable earnings', in I.T. Vanderhoof and E.I. Altman (eds) The Fair Value of Insurance Liabilities, New York: Kluwer.

Booth, P.M., Chadburn, R., Cooper, D., Haberman, S. and James, D. (1998) Modern Actuarial Theory and Practice, Boca Raton: CRC Press.

Cant, M.A. and French, D.A. (1993) 'Margin on services reporting: The financial implications', Presented to Institute of Actuaries of Australia Sessional Meeting.

Dickinson, G. (2003) 'The search for an international accounting standard for insurance', The Geneva Papers on Risk and Insurance - Issues and Practice 28(2): 151-175.

Dickinson, G. and Liedtke, P. (2004) 'Impact of a fair value financial reporting system on insurance companies: A survey', The Geneva Papers on Risk and Insurance - Issues and Practice 29(3): 540-581.

Doll, D.C., Elam, C.P., Hohmann, J.E., Keating, J.M., Kolsrud, D.S., MacDonald, K.O., McLauglin, S.M., Merfeld, T.J., Reddy, S.D., Reitano, R.R., Robertson, R.S., Robbins, E.L., Rogers, D.Y. and Siegel, H.W. (1998) 'Fair valuation of life insurance company liabilities', in I.T. Vanderhoof and E.I. Altman (eds) The Fair Value of Insurance Liabilities, New York: Kluwer.

Dullaway, D. and Bice, A. (2002) 'How fair is fair value?' Insight 2: 18-22.

Economist (2004) 'Fair value in insurance', Economist, 23 April.

Financial Accounting Standards Board (1982) Statement of Financial Accounting Standards No. 60, Accounting and Reporting by Insurance Enterprises, Norwalk: FASB.

German Accounting Standards Board (2000) GAS 5-20. Risk Reporting by Life Insurance Firms, Frankfurt: GASB. 
Gutterman, S. (2000) 'The valuation of future cash flows: An actuarial issues paper', in I.T. Vanderhoof and E.I. Altman (eds) The Fair Value of Insurance Business, New York: Kluwer Academic Publishers.

Hairs, C.J., Belsham, D.J., Bryson, N.M., George, C.M., Hare, D.J.P., Smith, D.A. and Thompson, S. (2002) 'Fair valuation of liabilities', British Actuarial Journal 8(II): 203-299.

Harrington, S. (1990) 'Insurance accounting', in S. Harrington and G. Dionne (eds) Handbook of Insurance Economics, New York: Cambridge University Press.

Horton, J. and Macve, R. (1995) Accounting Principles for Life Insurance: A True and Fair View? London: Institute of Chartered Accountants in England and Wales.

Horton, J. and Macve, R. (1999) 'Planned changes in accounting principles for U.K. life insurance companies: A preliminary investigation of stock market impact', Journal of Business Finance and Accounting 25(7): 137-158.

International Accounting Standards Board (2001) Insight, London: International Accounting Standards Board.

IASB (Insurance Steering Committee) (2002) Insurance: Draft Statement of Principles, London: IASC.

IASB (2004) IFRS 4: Insurance Contracts, London: IASC.

IASB (2007) Discussion Paper: Preliminary Views on Insurance Contracts, London: IASB.

International Accounting Standards Committee (1993) IAS 18. Revenue, London: IASC.

Joint Working Group of the FASB AASB ASB and CICA (2001) Proposals for a Fair Value Standard for Financial Instruments.

Jorion, P. (1997) Value at Risk, New York: McGraw-Hill.

Klumpes, P.J.M. (1999) 'Measuring the profitability of proprietary U.K. life insurance companies', British Accounting Review 31(2): 185-204.

Klumpes, P.J.M. and Shackleton, M.B. (2000) 'Valuing the strategic option to sell life insurance business: Theory and evidence', Journal of Banking and Finance 24: 1681-1702.

Linsmeier, T.J., Boatsman, J.R., Herz, R.H., Jennings, R.G., Jonas, G.J., Lang, M.H., Petroni, K.R., Shores, D. and Wahlen, J.M. (1998) 'Response to a discussion paper issued by the IASC/CICA steering committee on financial instruments "Accounting for Financial Assets and Financial Liabilities", Accounting Horizons 12(1): 90-98.

McGurk, P. (1998) 'Traded endowments', British Actuarial Journal 4(III): 485-524.

Michel, M.L. (1999) 'Earnings, historical cost book values, and fair-value disclosures in the valuation of stock life insurance companies', in I.T. Vanderhoof and E.I. Altman (eds) The Fair Value of Insurance Business, New York: Kluwer.

Multidisciplinary Working Group on Enhanced Disclosure (2001) Final report to Basel Committee.

O'Brien, C. (1994) 'Profit, capital and value in a proprietary life assurance company', Journal of the Institute of Actuaries 121: 285-339.

Penman, S.H. (1996) 'The articulation of price-earnings ratios and market-to-book ratios and the evaluation of growth', Journal of Accounting Research 34: 235-259.

Penrose, L. (2004) Report of the Equitable Life Inquiry, London: HM Treasury.

Petroni, K. and Wahlen, J. (1995) 'Fair values of equity and debt securities and share prices of propertyliability insurance companies', Journal of Risk and Insurance 62(4): 719-737.

Pindyck, R.S. (1988) 'Irreversible investment, capacity choice and the value of the firm', American Economic Review 78: 969-985.

Reitano, R.R. (1995) 'Two paradigms for the market value of liabilities', North American Actuarial Journal 1(4): 104-122.

Royal \& Sun Alliance (2004) Annual report and accounts 2003.

Sheldon, T.J. and Smith, A.D. (2004) 'Market-consistent valuation of life assurance business', British Actuarial Journal 10(3): 543-605.

Skerman, R. (1966) 'A solvency standard for life assurance business', Journal of the Institute of Actuaries 92 : 75-84.

Upton, W. (1997) A Primer on Accounting Models for Long-Duration Life Insurance Contracts under U.S. GAAP. Financial Accounting Series No. 167-A, Norwalk: FASB.

Wallace, M. (2002) 'Performance reporting under fair value accounting', North American Actuarial Journal 6(1): 28-61.

Welzel, H.-J. (1996) 'The concept of prudence in EC insurance accounts law', The Geneva Papers on Risk and Insurance - Issues and Practice 21: 36-49. 


\section{About the Authors}

Paul J.M. Klumpes is Professor of Accounting at Imperial College Business School, London. Paul holds Bachelor degrees in Commerce and Law, a Masters degree in Commerce and a PhD in Accounting. He is also an Australian CPA and Honorary Fellow of the Institute of Actuaries. His research interests cover the inter-relationship of public policy and voluntary reporting, regulation, financial management and control of financial services, particularly related to pensions and life insurance.

Christopher D. O'Brien is Director of the Centre for Risk and Insurance Studies at Nottingham University Business School. He has a degree in Economics and is a Fellow of the Institute of Actuaries. His research interests include the financial management and regulation of and accounting for insurance companies and pension funds, together with risk management by financial and non-financial companies.

Andres Reibel is a PhD Finance student at Imperial College Business School in London. He holds an MSc in Finance from the same and an undergraduate degree in Business Studies from the University of Cooperative Education, Mannheim. His research interests include equity valuation, competitive strategy, management quality and investments in special situations. 